\title{
Contribution of non-pollen palynomorphs to reconstructions of land-use changes and lake eutrophication: case study from Lake Jaczno, northeastern Poland
}

\author{
Dawid Weisbrodt ${ }^{1 *}$, Dirk Enters ${ }^{2,3}$, Maurycy Jacek Żarczyńskii ${ }^{1}$, Anna Izabela Poraj-Górska ${ }^{1}$, \\ Wojciech Tylmann ${ }^{1}$
}

\begin{abstract}
${ }^{1}$ University of Gdańsk, Faculty of Oceanography and Geography, Bażyńskiego 4, 80-309 Gdańsk, Poland, e-mail: d.weisbrodt@ug.edu.pl ( ${ }^{*}$ orresponding author); anna.porajgorska@phdstud.ug.edu.pl; maurycy.zarczynski@phdstud.ug.edu.pl; wojciech.tylmann@ug.edu.pl ${ }^{2}$ University of Bremen, Institute of Geography, GEOPOLAR, Celsiusstr. FVG-M, D-28359 Bremen, Germany, e-mail: enters@uni-bremen.de ${ }^{3}$ Lower Saxony Institute for Historical Coastal Research, Viktoriastr. 26/28, 26382 Wilhelmshaven, Germany
\end{abstract}

\begin{abstract}
Analysis of non-pollen palynomorphs supplemented by pollen analysis, microcharcoal analysis and geochemical data from laminated sediments from Lake Jaczno were used to establish different phases of land-use in the catchment between c.a. AD 1840 and AD 2013. The results show that during the first eighty years the vicinity of the lake was heavily deforested. During this period erosional inputs caused accumulation of abundant fungal spores, indicators of pastures and natural fertilizers (manure) as well as of corroded pollen grains and charcoal. Gradual regeneration of forest cover took place after World War II, when expansion of pioneer trees occurred (Betula, Salix, Carpinus, Populus). At the same time, a considerable increase in the lake trophy was observed, leading to the changes in phytoplankton and macrophyte communities: a decrease in the proportion of Botryococcus and an increase in the Nymphaea alba population. The non-pollen palynomorphs analyses indicate the substantial human impact that caused changing local environmental conditions, compatible with the results based on pollen analysis and geochemical data.
\end{abstract}

Key words: lake sediments, non-pollen palynomorphs, pollen, secondary succession, varves

\section{Introduction}

The past two centuries have been marked by a considerable increase in human-induced impact on the natural environment. A particular intensification of this process has been observed since the mid- $20^{\text {th }}$ century, which has ultimately led to the concept of a new stratigraphical unit, the Anthropocene (Waters et al. 2016). In order to facilitate a deeper understanding of natural and anthropogenic transitions of ecosystems it is vital to trace the processes within a broader temporal framework. That goal may be attained through research of lake sediments which serve as an archive of the processes occurring in lake ecosystems and within their catchment areas. Annually laminated sediments are particularly useful for such reconstructions because of their ability to provide a calendar-year chronology of the observed environmental changes. In recent years, the number of multi-proxy reconstructions using annually laminated lake sediments has been systematically increasing, which provides a chance for better understanding the natural and human-induced changes of ecosystems (Tylmann et al. 2013; Zolitschka et al. 2015). Non-pollen palynomorphs (NPP) is a common name for various groups of organic remains (e.g. green algae, cyanobacteria, fungi) which are preserved during pollen preparation (van Geel 2001). NPP analysis is a very useful tool for reconstruction of local environmental conditions, i.e. phases of soil erosion, fire events, trophic changes or the presence of herbivores (van Geel 2001; van Geel et al. 2003; van Geel and Aptroot 2006). For this reason, in recent decades it has become an important complement of many palynological studies (Miola 2012; Baker et al. 2013). In Poland, the number of detailed NPP studies has also been continuously rising (Latałowa et al. 2013; Kołaczek et al. 2013; Szal et al. 2016). However, there is still a need for highresolution investigations using well-dated sediment cores from the Late Holocene. In Europe, the past two 

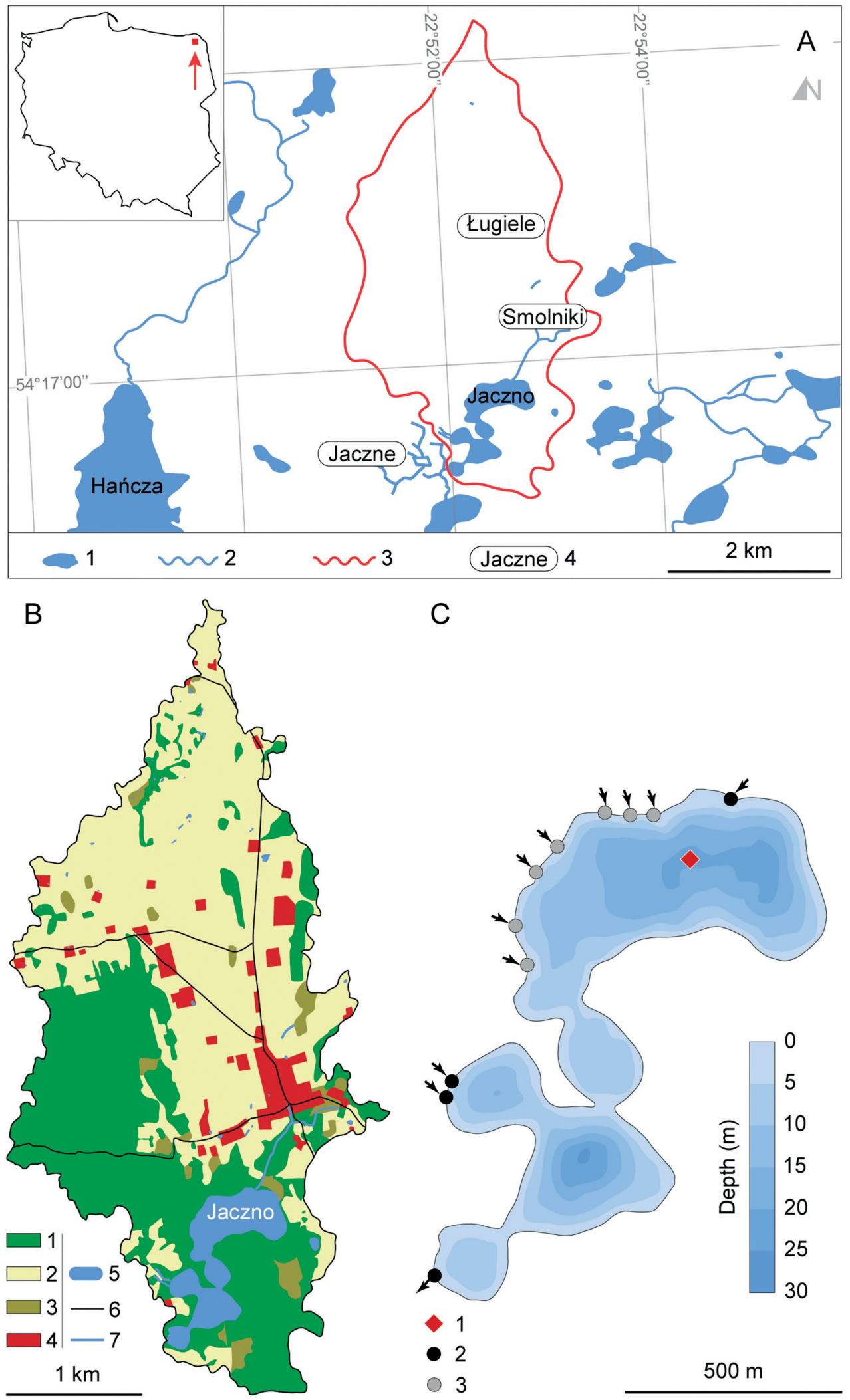

C

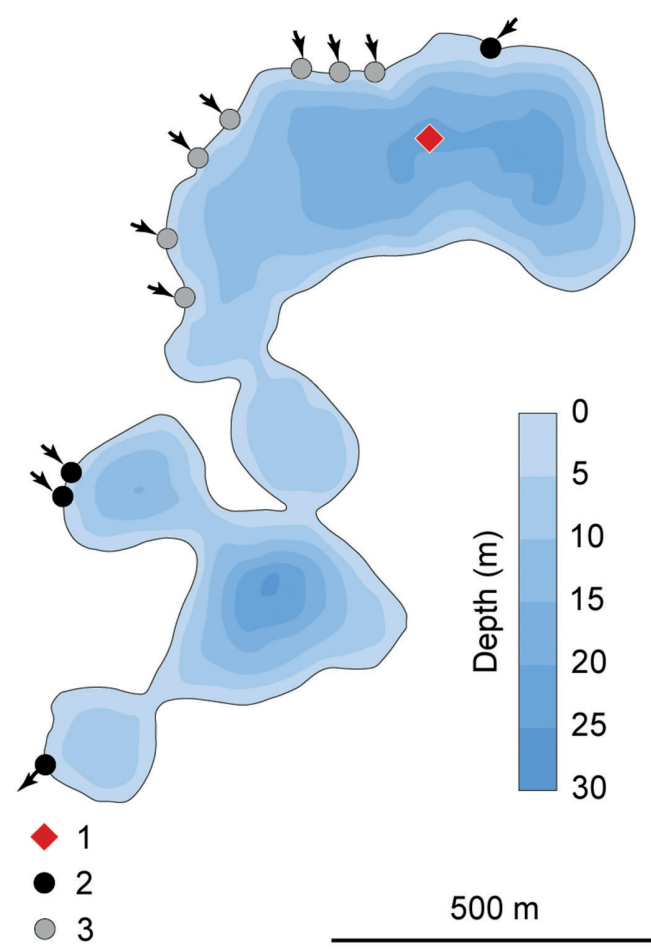

Fig. 1. Study site. (A) Location of Lake Jaczno: 1 - lakes, 2 - main watercourses, 3 - catchment area, 4 - villages; (B) Land use of the Lake Jaczno catchment: 1 - forests, 2 - croplands, 3 - meadows and other open lands, 4 - settlements, 5 - lakes and ponds, 6 - main roads, 7 watercourses; (C) Lake bathymetry: 1 - coring site, 2 - permanent streams, 3 - periodic streams 
hundred years were characterised by substantial changes in land-use management caused by alternate deforestation and secondary succession processes (Ericsson et al. 2000). These changes also had a significant influence on lake ecosystems, e.g. fostered eutrophication processes (Smoll 2008). Lake Jaczno holds a high-resolution sedimentological record of land-use changes in the catchment. These processes were investigated using precise sediment chronology and a range of sedimentological, geochemical and pollen analyses supported by information derived from the analysis of historical maps and documentary sources (Poraj-Górska et al. submitted). In this paper we have drawn on already published results of geochemical and pollen analyses as a background for investigations of non-pollen palynomorphs in recent sediments of Lake Jaczno. Our goal is to show how the changes in local land-use management and trophic status of the lake during the last two hundred years are reflected in the NPP record.

\section{Study site}

Lake Jaczno is located in the Suwałki Lake District, northeastern Poland. The catchment morphology developed mostly during the Pomeranian Phase of the Weichselian glaciation period (ca. $15.2 \mathrm{ka} \mathrm{BP}$ ) (Ber 1982). Well preserved post-glacial forms, diverse topography and large changes in elevation (from 163 to $280 \mathrm{~m}$ a.s.l.) are characteristic features of the vicinity of Lake Jaczno. The surface geology consists of moraine tills, fluvioglacial gravels, sands and silts, as well as sands and gravels with boulders. Locally, peatlands occur. On such deposits three main soils have formed: cambisols, ferralic cambisols and podzols. The first can be found in the eastern part of the catchment, where also most of the buildings and agricultural lands are located. The other two soil types are situated in the southeastern and eastern parts, which are covered by forest. Lake Jaczno has three permanent and several periodic inflows that mainly supply the northern basin (Fig. 1). One outflow (Jacznówka) drains the waters southward to the Szeszupa River.

The total surface area of the lake is 40.6 ha which can be divided into five basins (Fig. 1). The lake is dimictic with a strong water column stratification during summer, inverse stratification in winter and mixing periods in spring and fall. The present trophic status of Lake Jaczno can be described as mesotrophic (Górniak et al. 2007).

\section{Methods}

Core JAC-13/1 was taken from the deepest part of the northern basin at a water depth of $20.5 \mathrm{~m}$ (Fig.
1) using a UWITEC gravity corer $(\Phi 90 \mathrm{~mm})$. The core was transported to the GEOPOLAR laboratory at the University of Bremen, split lengthwise, described macroscopically, photographed and stored at $6^{\circ} \mathrm{C}$ prior to further analyses. Detailed descriptions of methods used are presented in Poraj-Górska et al. (submitted).

Calendar-year chronology for the sediment record was obtained by varve counting. The annual nature of laminations was verified by microscopic analysis of thin sections prepared from impregnated sediment slabs. Varve counting was performed on high-resolution digital images of the scanned thin sections and verified using microscopic analysis. Biogenic varves with characteristic laminae consisting of autochthonous calcite crystals were recognized as typical, yet significant minerogenic inputs led to the formation of clastic laminae in some parts of the sediment record. The varve-based time scale was verified by comparison with ${ }^{137} \mathrm{Cs}$ activity peaks in the sediments. Gamma-ray spectrometry was carried out using an HPGe well-type detector (GCW 2021, Canberra) according to the procedures presented in detail by Tylmann et al. (2016).

One half of the split core was subsampled with a 3-year temporal resolution based on visible varve boundaries. Analysis of Carbon, Nitrogen and Sulfur (CNS) were performed with a EuroEA (Eurovector) elemental analyzer. At first step total carbon (TC), total nitrogen (TN) and total sulfur (TS) were measured on freeze-dried and homogenized samples. After removal of carbonates with $\mathrm{HCl}$, total organic carbon (TOC) was analyzed. Total inorganic carbon (TIC) was calculated as the difference between TC and TOC (Enters et al. 2009). The content of biogenic silica (BSi) was analyzed using a segmented flow procedure after digestion of dry sediment in $1 \mathrm{M} \mathrm{NaOH}$ at $85^{\circ} \mathrm{C}$ (Müller and Schneider, 1993). Minerogenic matter (MM) content was estimated by deduction of $\mathrm{BSi}, \mathrm{CaCO}_{3}$ and organic matter contents from 100\% (Enters et al. 2008).

Pollen samples $\left(1 \mathrm{~cm}^{3}\right)$ containing three varves were taken and every second sample was analyzed. Samples were first treated with $\mathrm{HF}, \mathrm{HCl}$ and boiled in $\mathrm{KOH}$ and then acetolyzed and mounted in glycerine on microscope slides (Feagri and Iversen 1989). To calculate the concentration of palynomorphs Lycopodium clavatum tablets were added (Stockmarr 1971). Pollen and spores were identified using pollen keys by Moore et al. (1991) and Beug (2004), and the reference collection at the Department of Geomorphology \& Quaternary Geology, University of Gdańsk. Due to generally low concentration 300-600 pollen grains per sample were counted. Non-pollen palynomorphs were identified following van Geel (2001), van Geel et al. (2003) and Komárek and Jankovská (2001). Proportions of pollen/spores of terrestrial taxa, were calculated on the sum of AP (Arboreal 
Pollen) + NAP (Non-Arboreal Pollen) (excluding sporomorphs of aquatic and wetland plants, corroded pollen grains, charcoal and NPP). Proportions of aquatics and wetland, corroded pollen, charcoal and NPP were calculated on the sum of AP + NAP + the number of spores, pollen or NPP of the respective taxa. Stratigraphic diagrams of relative abundance were created with the rioja package for R (Juggins 2015). Ordination by principal component analysis (PCA) was used to display the relationship between pollen, NPP and geochemical data. PCA was implemented by PAST 3.14 software (Hammer et al. 2001).

\section{Results}

Sediment lithology, chronology and composition

Based on the lithological description and sediment composition, the analyzed sediment core can be divided into four lithological units (Fig. 2). Unit I (83$40 \mathrm{~cm}$ ) is characterized by a distinct clastic-biogenic lamination. The highest proportions of MM, as well as maximum TOC/TN ratio are observed. Simultaneously other sediment components (TOC, TIC, TN) show their minima. Biogenic silica fluctuates with local maxima at the depth of 79 and $52 \mathrm{~cm}$. Unit II (40-30.5 $\mathrm{cm}$ ) is a massive layer of mainly minerogenic material with irregular admixtures of organic remains. Unit III $(30.5-17 \mathrm{~cm})$ is characterised by slightly disturbed laminations with a higher proportion of TOC, TIC, TN and $\mathrm{BSi}$, as well as a gradual decline in the MM content. Laminations in Unit IV $(17-0 \mathrm{~cm})$ become more regular and very well preserved. The minerogenic matter content fluctuates at a generally low level while BSi, TIC, TOC and TN simultaneously increase.

Calendar-year chronology for the sediment record was provided by varve counting. The varve-based time scale corrected for slumps and erosion events reaches back to $1839^{+11} /$ (Poraj-Górska et al. submitted). Relatively high uncertainty $(4-6 \%)$ is caused by some indistinctly defined varves in units I and II. Reliability of the chronology was confirmed by the position of ${ }^{137} \mathrm{Cs}$ activity peaks. Two distinct maxima related to

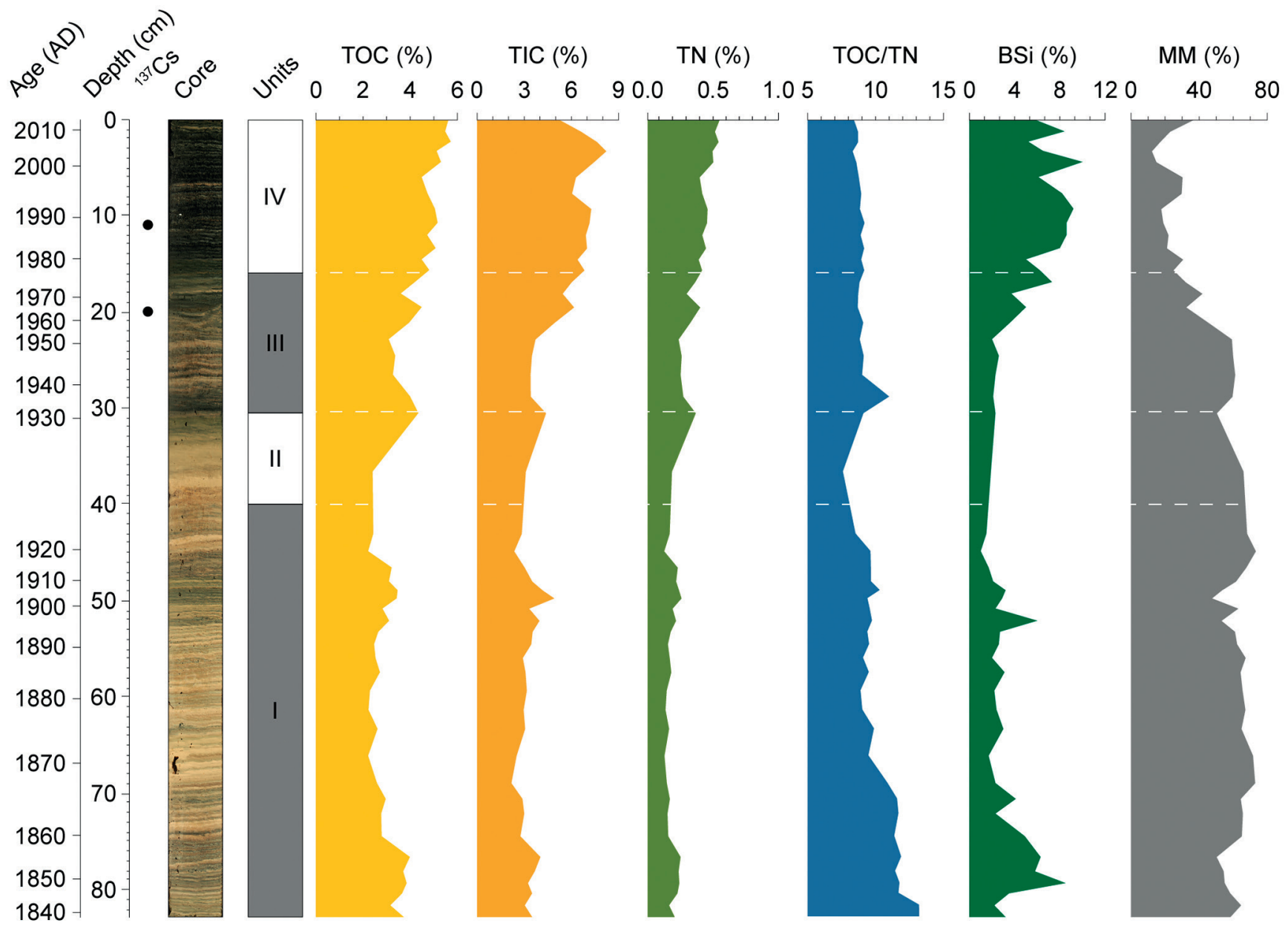

Fig. 2. Percentage geochemical diagram from Lake Jaczno. Black dots $-{ }^{137}$ Cs activity peaks, description of lithological units is given in the text (modified from Poraj-Górska et al. submitted) 
the maximum intensity of atmospheric nuclear weapon tests in 1963 and the fallout resulting from the release of radioactive nuclides following the 1986 Chernobyl reactor accident correspond very well to the varve chronology (Fig. 2).

Pollen and non-pollen palynomorphs analysis

The total sum of 27 samples from the JAC-13/1 core is divided into two biozones, with two subzones (1a and 1b) (Fig. 3). The zonation is mainly based on the percentages of fungal spores and pollen indicators of human activity which indicate periods of higher erosion and the presence of open habitats such as pastures and croplands. Their boundaries also correspond to the main lithological units. Unit II $(40-30.5 \mathrm{~cm})$ is an exception, as the extremely low concentration of sporomorphs prevents a quantitative analysis.

\section{Biozone 1a $(83-40 \mathrm{~cm})$ :}

This zone is characterised by highest diversity and frequency of fungal spores, i.e. Glomus, Sordaria,
Sporormiella, Chaetomium, Kretzschmaria deusta and Diporotheca as well as the maximum proportion of micro-charcoals, with a distinct peak of around 1860 . Correspondingly, peaks of the microcharcoal fraction over $100 \mu \mathrm{m}$ are correlated with the presence of spores of Gelasinospora.

Pollen analysis showed that this period is characterised by the highest proportion of NAP (up to 45\%). Among cultivated plants Secale cereale clearly dominates, with values reaching from 3 to $5 \%$. It is accompanied by segetal weeds, such as Centaurea cyanus as well as taxa typical of ruderal habitats: mugwort (Artemisia), and members of the goosefoot family (Chenopodiacae). Species typical for pastures and wet meadows are represented by Plantago lanceolata, Plantago media, Aster-t., Ranunculus acris-t. and Cyperaceae. Among phytoplankton communities Botryococcus and Tetraedron dominate. Additionally, slight quantities of Pediastrum integrum, Pediastrum kawrayski, Pediastrum orientale were recorded. Cyanobacteria were represented by a few specimens of Gloeotrichia and Rivularia.
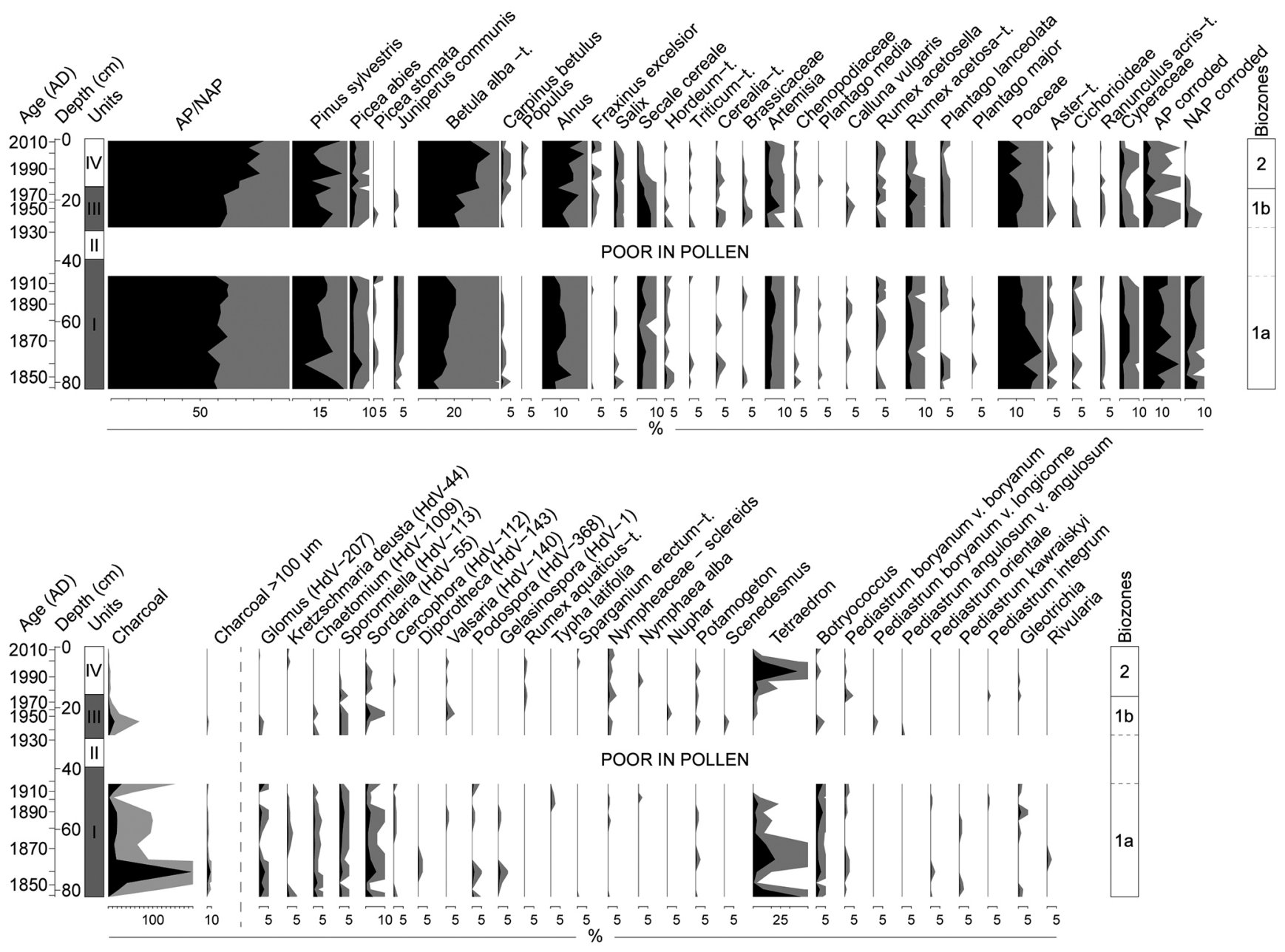

Fig. 3. Percentage pollen and non-pollen palynomorphs diagram from Lake Jaczno (selected taxa, lithological units as in Figure 2) 
Biozone 1b $(29-17 \mathrm{~cm})$ :

This zone is mainly characterized by a gradual decrease in the proportion of fungal spores, especially Glomus and Chaetomium. Pollen analysis showed increased participations of Alnus, Salix, Fraxinus pollen and a dramatically decreased proportion of Juniperus. The proportion of Secale cereale remains at a high level (up to 7\%). In the upper part of the zone distinct peaks of Artemisia and Rumex acetosa-t. were recorded. Compared to biozone 1 clearly lower proportions of microcharcoal and corroded pollen are observed. Phytoplankton communities are characterised by a decrease in the proportion of Botryococcus, smaller quantities and lower diversity of the Pediastrum genus. Among them a few coenobia of $P$. boryanum var. longicorne and $P$. angulosum var. angulosum were recorded.

\section{Biozone $2(17-0 \mathrm{~cm})$ :}

In this zone, a further decrease in diversity and quantities of fungi spores and a minimum percentages of micro-charcoal and corroded pollen grains are observed. This also corresponds with maximum values of arboreal pollen (up to $86 \%$ ). This increase is mainly due to pioneer species such as Betula, Carpinus and Populus. Simultaneously, a decrease of all anthropogenic indicators, particularly Secale cereale was recorded. In the aquatic environment a distinct increase in the participation of Tetraedron and Nympheacae sclereids is recognisable, while Botryococcus almost completely disappear.

\section{Discussion}

\section{Changes in terrestrial environment}

The analysis of pollen and NPP from Lake Jaczno allows three contrasting periods in terms of vegetation composition and character of sedimentary processes to be differentiated.

The period between ca. 1840 and 1920 (Biozone 1a) is characterised by a high participation of anthropogenic pollen indicators. A high proportion of Secale cereale accompanied by segetal weeds, such as Centaurea cyanus clearly indicates croplands in the close vicinity of the lake. Other abundant pollen types are Poaceae, Rumex acetosa-t. and Rumex acetosella. These species are present in various types of open habitats: meadows, pastures and ruderal habitats (Behre 1981). The presence of Plantago lanceolata and other taxa typically found in pastures (Plantago media, Aster-t., Ranunculus acris-t.) is indicative of grazing. Another proof of the presence of pastures in the direct vicinity of the lake is the maximum frequency of coprophilous fungi (Sporormiella, Sordaria, Podopospora, Cercophora and Chaetomium). Among them, Sporormiella in particular is a typical indicator of the local presence of dung of domestic herbivores (Baker et al. 2013). In Lake Jaczno values of Sporormiella reached 3\% and according to Davis and Shafer (2006) such high values are associated with an occurrence of livestock near the lake shore. This temporal relationship between the sum of pollen typical for meadow habitats and coprophilous fungal spores is clearly supported by the PCA analysis (Fig. 4). However, it is reasonable to suppose that the presence of some of the coprophilous fungi spores is also related to the contamination of lake waters with organic fertilizer runoff from cropland. Such a scenario may be further supported by the presence of Chaetomium which frequently populates manure composed of a mixture of dung and straw (Ellis and Ellis 1989).

A high deforestation rate in the catchment area of Lake Jaczno intensified erosion processes and caused a higher input of minerogenic matter in the sediments (Fig.2). Additionally, the high proportion of Glomus whose chlamydospores form endomycorrhiza with various plant species (Anderson et al. 1984) is another strong signal of intensive erosion processes within the catchment area of the lake (van Geel et al. 1989; Bos et al. 2006; van Geel et al. 2011).

Another group of spores comprises carbonicolous/lignicolous fungi, which include Diporotheca and Kretzschmaria deusta. These fungi belong to typical pathogens of deciduous trees (van Geel et al. 2013; van Geel and Andersen 1988; Innes et al. 2006; Latałowa et al. 2013) and their presence can also be linked to unstable soil conditions (López-Merino et al. 2012; Reveles and van Geel 2016). In addition, small amounts of pirophitic Gelasinospora spores were identified. Its presence serves to confirm the local nature of fires in the period and coincides with the maximum proportion of microcharcoal in the sediments, including those with a diameter exceeding 100 micrometers (Innes and Blackford 2003). Their relatively high occurrence throughout the discussed period may be interpreted mainly as a consequence of the redeposition of burnt organic matter deposited in the surface layer of the soil in the context of increased erosion caused by deforestation. Both, fires in open areas (e.g. spring grassland fires) and burning wood in domestic stoves are potential sources of microcharcoal in the sediments.

A characteristic feature of this phase is also the high abundance of corroded pollen grains. There may be different reasons for the corrosion of pollen and spores (Tweddle and Edwards 2010). In sediments of Lake Jaczno, two types of grain corrosion were clearly dominant. First, commonly oval cavities in the form of local etching and pitting. Markings of this sort appear as a result of the impact of oxidation processes on the surface of the exine. They may also be sign of 


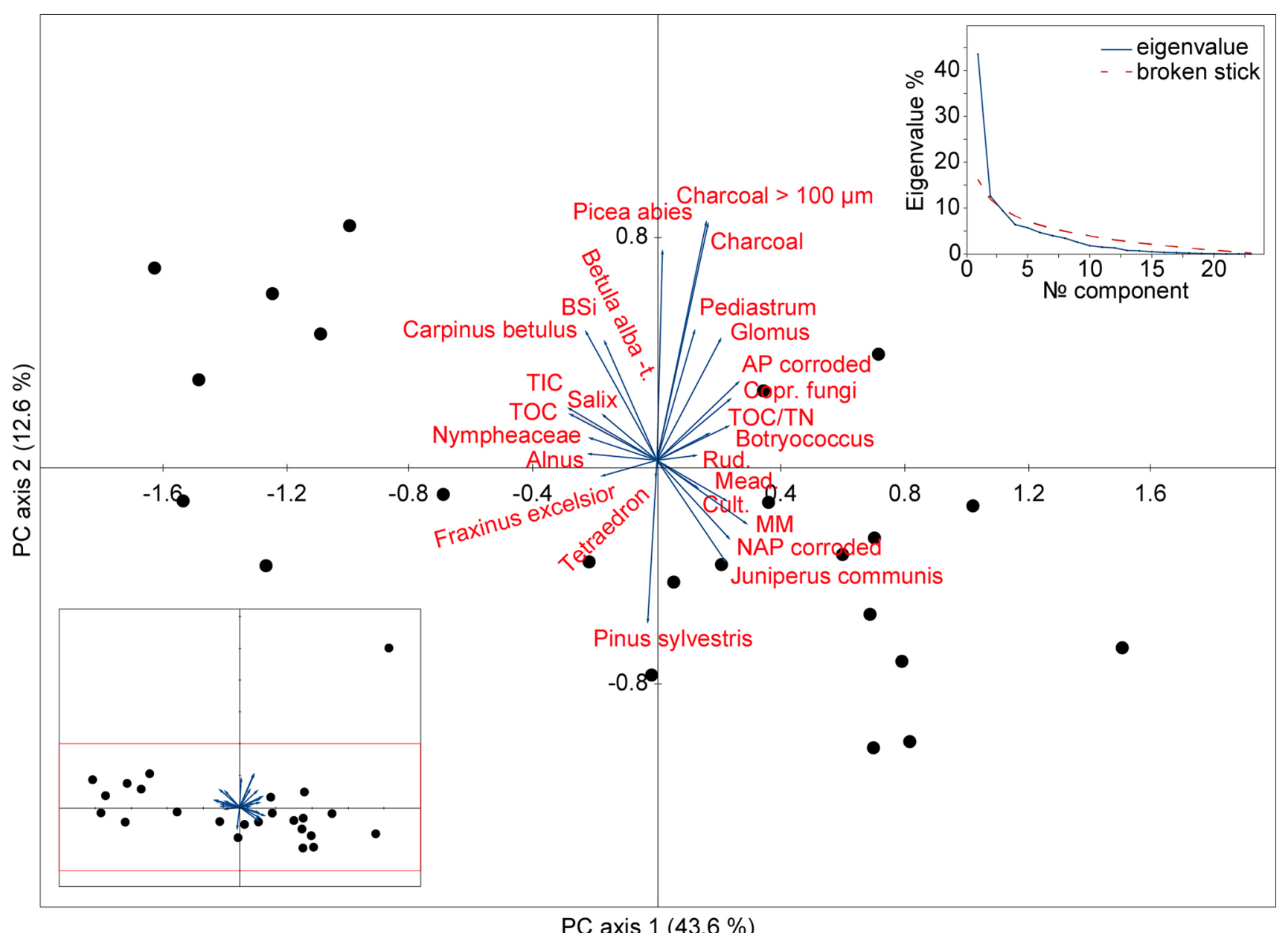

Fig. 4. PCA diagram; CULT - sum of cultivated taxa, RUD - sum of ruderal taxa, MEAD - sum of meadow taxa, CoprFungi - sum of coprophilous fungi

fungi and bacteria activity (Havinga 1984). The second group comprises broken and cracked grains. This type of corrosion is usually associated with the washing out of minerogenic sediments derived from the catchment area (Birks 1970; Brown et al. 2007; Tipping 1995). In both cases deteriorated pollen grains may be treated as an indicator of erosion processes. The PCA results support this view, as they indicate the correlation between the percentage of corroded pollen (both AP and NAP) and the minerogenic matter content in the sediment. This is indicative of redeposition of the pollen in the context of deforestation of the catchment area. Interrelationships of this kind have been observed on numerous sites (Tolonen 1980; Wilmhust and McGlone 2005). Moreover, TOC/TN ratio values higher than 10 suggest a significant input of terrestrial organic matter in the sediments (Enters et al. 2006; Meyers 2003).

The massive layer (Unit II) contained an extremely low concentration of sporomorphs and other biotic components of sediments, including diatoms.
This points to a terrestrial origin of the sediments and potentially rapid sedimentation.

The next biozone (1b) is characterised by an increase in the proportion of species typical of wet habitats: black alder (Alnus glutinosa), willow (Salix) and common ash (Fraxinus excelsior). These changes indicate the gradual expansion of trees in wet habitats on the shores of the lake. At the same time an increase in the proportion of birch pollen is observed, which may represent two species: downy birch Betula pubescens and silver birch $B$. pendula. The former is found, inter alia, in wetlands or wet habitats, whereas the latter is often present as a pioneer plant in anthropogenically distorted habitats (Zarzycki 1979). The expansion of the aforesaid species coincides with the disappearance of the light-demanding Juniperus. A higher proportion of Brassicaceae pollen is also noted which may be linked to the spread of rape (Brassica napus) cultivation in Poland from the 1960s (Bartkowiak-Broda 2002). In the upper part of this biozone a significant increase in 
the presence of ruderal species (Artemisia and Rumex acetosa-t.) is observed, accompanied by a decrease in the proportion of cereals. This phenomenon dates back to the early 1950s and it may be linked with secondary succession on abandoned fields. A very similar scenario in the corresponding period was observed in the sediments of Lake Żabińskie (Wacnik et al. 2016). This process could coincide with the socio-economic changes which took place in those areas after World War II. The gradual regeneration of former fields and pastures with trees and ruderal plants triggered a reduction in the intensity of erosion processes. That, in turn, resulted in a slightly lower proportion of minerogenic matter in the sediment. A decrease is also noted in the frequency of pollen with traces of corrosion caused by erosion processes, as well as the amount and diversity of fungi spores. The proportion of micro-charcoal is also lower including a decline in fragments over 100 micrometers. Biozone 2 dates from the early 1970s when a rapid change in the character of vegetation is observed. There is a notable decrease in the participation of cereals and other anthropogenic indicators. At the same time, an increase is noted in pioneer species such as birch (Betula), hornbeam (Carpinus) and poplar (Populus). The process constitutes another stage of secondary succession as a consequence of land-use change. The development of forest cover and stabilisation of the substrate occurred alongside a decrease in the intensity of mechanical denudation; therefore, the proportion of corroded pollen and other erosion indicators (fungal spores) further declined.

\section{Changes in aquatic environment}

As the coring site is situated in the deepest part of the northern basin, the contribution of water and wetland plant remains is generally low in the analysed material. The regular presence of coenobia of Botryococcus, Tetraedron with the co-occurrence of several taxa of Pediastrum type (single cenobia of Pediastrum integrum, Pediastrum kawraiskyi, Pediastrum orientale) suggest rather low primary productivity (Jankovská and Komárek 2000). From the 1940s onwards, the disappearance of Botryococcus, is observed, which is in parallel with a higher trophic level of the lake manifested by the increase in TIC, TOC, TN and BSi contents. The decrease in the proportion of Botryococcus may be related to competition processes among various groups of phytoplankton during increasing eutrophication. Moreover, the increased proportion of Nymphaeaceae-sclereids is indicative of increased trophy levels. This phenomenon is also very distinct in the PCA diagram, where TOC, TIC, TN and BSi are correlated with Nymphaeaceae-sclereids. An increase in the trophic level in a corresponding period was also observed in the southern basin of Lake Jaczno (Butz et al. 2016) and in Lake Żabińskie (Amann et al. 2014) as well as in many regions of Europe (Hobæk et al. 2012; Kienel et al. 2013; Leeben et al. 2013). The increased proportion of nympheids may also be explained by an increased range of the littoral zone as a result of water level changes (Rasmussen and Anderson 2005). Such a hypothesis seems to be supported by the higher proportion of willow and alder, which may be indicative of hydrological changes. Hydrological changes are also reflected in the analysis of historical maps which indicate that the major inflow of Lake Jaczno was shortened by nearly $2 / 3$ between 1839 and 1941 (Poraj-Górska et al. submitted).

\section{Conclusions}

The analysis of NPP, pollen, charcoal and geochemical data has provided detailed information about the palaeo-environmental evolution of the Lake Jaczno and its catchment during the last ca. 200 years. The Principal Component Analysis clearly demonstrates that major NPP fluctuations corresponded with landuse changes and eutrophication processes reflected by pollen and geochemical analysis. The main conclusions can be summarized as follows:

- during the period between 1840 and 1950 the lake catchment was covered mainly by a mosaic of pastures, ruderal habitats and croplands,

- the coexistence of chlamydospores of Glomus, corroded pollen grains and significant amounts of minerogenic matter in the sediment suggest intense erosional processes in the lake catchment,

- high quantities of the coprophilous fungi indicate the presence of pastures in the direct vicinity of the lake as well as organic fertilizer runoff from cropland,

- high abundance of microcharcoal and the presence of pyrophitic Gelasinpospora suggest frequent local fire events at that time,

- after World War II a gradual secondary succession on meadows and croplands took place,

- at the same time a progressive lake eutrophication caused changes in phytoplankton communities (decrease of Botryococcus) and an increase of Nymphaea alba.

\section{References}

Amann B., Lobsiger S., Fischer D., Tylmann W., Bonk A., Filipiak J., Grosjean M., 2014, Spring temperature variability and eutrophication history inferred from sedimentary pigments in the varved sediments of Lake Żabińskie, north-eastern Poland, AD 1907-2008, Glob. Planet. Change 123: 86-96. 
Anderson R.S., Homola R.L., Davis R.B., Jacobson Jr G.L., 1984, Fossil remains of the mycorrhizal fungal Glomus fasciculatum complex in postglacial lake sediments from Maine, Can. J. Bot. 62(11): 2325-2328.

Baker A.G., Bhagwat S.A., Willis K.J., 2013, Do dung fungal spores make a good proxy for past distribution of large herbivores?, Quat. Sci. Rev. 62: 21-31.

Bartkowiak-Broda I., 2002, Wzajemny zwiazek postepu $\mathrm{w}$ agrotechnice i hodowli rzepaku ozimego (Mutual progress in agricultural practices and winter rape farming), Oilseed Crops 23(1): 61-71 (in Polish).

Behre K.E., 1981, The interpretation of anthropogenic indicators in pollen diagrams, Pollen et spores 23(2): 225-245.

Ber A., 1982, Marginal zones and deglaciation during the North Polish Glaciation in the Suwałki-Augustów Lakeland, Biul. Inst. Geol. 343: 71-89.

Beug H., 2004, Leitfaden der Pollenbestimmung für Mitteleuropa und angrenzende Gebiete, Verlag Friedrich Pfeil, Munich, 542 pp. (in German).

Birks H.J.B., 1970, Inwashed pollen spectra at Loch Fada, Isle of Skye, New Phytol. 69(3): 807-820.

Bos J.A., van Geel B., Groenewoudt B.J., Lauwerier R.C.M., 2006, Early Holocene environmental change, the presence and disappearance of early Mesolithic habitation near Zutphen (The Netherlands), Veget. Hist. Archaeobot. 15(1): 27-43.

Brown A.G., Carpenter R.G., Walling D.E., 2007, Monitoring fluvial pollen transport, its relationship to catchment vegetation and implications for palaeoenvironmental studies, Rev. Palaeobot. Palynol. 147(1): 60-76.

Butz C., Grosjean M., Poraj-Górska A., Enters D., Tylmann W., 2016, Sedimentary Bacteriopheophytin a as an indicator of meromixis in varved lake sediments of Lake Jaczno, north-east Poland, AD 1891-2010, Glob. Planet. Change 144: 109-118.

Davis O.K., Shafer D.S., 2006, Sporormiella fungal spores, a palynological means of detecting herbivore density, Palaeogeogr. Palaeoclimatol. Palaeoecol. 237(1): 40-50.

Ellis M.B., Ellis J.P., 1988, Microfungi on miscellaneous substrates: an identification handbook, Croom Helm, London, $244 \mathrm{pp}$.

Enters, D., Lücke, A., Zolitschka, B., 2006. Effects of land-use change on deposition and composition of organic matter in Frickenhauser See, northern Bavaria, Germany, Sci. Total Environ. 369: 178-187.

Enters D., Dorfler W., Zolitschka B., 2008, Historical soil erosion and land-use change during the last two millennia recorded in lake sediments of Frickenhauser See, northern Bavaria, central Germany, Holocene 18: 243-254.

Enters D., Kirilova E., Lotter A.F., Lücke A., Parplies J., Jahns S., Kuhn G., Zolitschka B., 2009, Climate Change and Human Impact at Sacrower See (NE Germany) during the past 13,000 years: a Geochemical Record, J. Paleolimnol. 43(4): 719-737.

Ericsson S., Östlund L., Axelsson A.L., 2000, A forest of grazing and logging: Deforestation and reforestation history of a boreal landscape in central Sweden, New For. 19(3): 227-240.

Faegri K., Iversen J., 1989, Textbook of pollen analysis, Willey, Chichester-Singapore, $328 \mathrm{pp}$.

Górniak A., Szumieluk D., Zielinski P., Suchowolec T., Jekatierynczuk-Rudczyk E., 2007, jeziora Suwalskiego Parku Krajobrazowego - aktualna trofia i jakość wód (Lakes of the Suwałki Landscape Park - current trophy and water quality), Mat. Konf. „Parki krajobrazowe w krajowym systemie ochrony obszarowej", Szelment 28-29 września 2006, Turtul, 31-36 (in Polish).

Hammer Ø., Harper D.A.T., Ryan P.D., 2001, PAST-PAlaeontological STatistics, ver. 1.89, Palaeontol. Electron. 4(1): $1-9$.

Havinga A.J., 1984, A 20-year experimental investigation into the differential corrosion susceptibility of pollen and spores in various soil types, Pollen et spores 6: 621-635.

Hobæk A., Løvik J.E., Rohrlack T., Moe S.J., Grung M., Bennion H., Clarke G., Piliposyan G.T., 2012, Eutrophication, recovery and temperature in Lake Mjøsa: detecting trends with monitoring data and sediment records, Freshwat. Biol. 57(10): 1998-2014.

Innes J.B., Blackford J.J., 2003, The ecology of late Mesolithic woodland disturbances: model testing with fungal spore assemblage data, J. Archaeol. Sci. 30(2): 185-194.

Innes J., Blackford J., Chambers F., 2006, Kretzschmaria deusta and the northwest European mid-Holocene Ulmus decline at Moel y Gerddi, north Wales, United Kingdom, Palynology 30(1): 121-132.

Jankovská V., Komárek J., 2000, Indicative value of Pediastrum and other coccal green algae in palaeoecology, Folia Geobot. 35(1): 59-82.

Juggins S., 2015, rioja: Analysis of Quaternary Science Data, $\mathrm{R}$ package version $0.9-9$.

Kienel U., Vos H., Dulski P., Lücke A., Moschen R., Nowaczyk N.R., Schwab M.J., 2013, Modification of climate signals by human activities recorded in varved sediments (AD 1608-1942) of Lake Holzmaar (Germany), J. Paleolimnol. 50: 561-575.

Kołaczek P., Zubek S., Błaszkowski J., Mleczko P., Margielewski W., 2013, Erosion or plant succession - how to interpret the presence of arbuscular mycorrhizal fungi (Glomeromycota) spores in pollen profiles collected from mires, Rev. Palaeobot. Palynol. 189: 29-37.

Komárek J., Jankovská V., 2001, Review of the green algal genus Pediastrum, Bibliotheca Phycologica 108, J. Cramer, Berlin-Stuttgart, $127 \mathrm{pp}$.

Latałowa M., Pędziszewska A., Maciejewska E., ŚwiętaMusznicka J., 2013, Tilia forest dynamics, Kretzschmaria deusta attack, and mire hydrology as palaeoecological proxies for mid-Holocene climate reconstruction in the Kashubian Lake District (N Poland), Holocene 23(5): 667-677.

Leeben A., Freiberg R., Tonno I., Koiv T., Alliksaar T., Heinsalu A., 2013, A comparison of the palaeolimnology of Peipsi and Võrtsjärv: connected shallow lakes in north- 
eastern Europe for the twentieth century, especially in relation to eutrophication progression and water-level fluctuations, Hydrobiologia 710(1): 227-240.

López-Merino L., Sánchez N.S., Kaal J., López-Sáez J.A., Cortizas, A.M., 2012, Post-disturbance vegetation dynamics during the Late Pleistocene and the Holocene: an example from NW Iberia, Glob. Planet. Change 92: 58-70.

Meyers P.A., 2003. Applications of organic geochemistry to paleolimnological reconstructions: A summary of examples from the Laurentian Great Lakes, Org. Geochem. 34: 261-289.

Miola A., 2012, Tools for Non-Pollen Palynomorphs (NPPs) analysis: A list of Quaternary NPP types and reference literature in English language (1972-2011), Rev. Palaeobot. Palynol. 186: 142-161.

Moore P.D., Webb J.A., Collinson M.E., 1991, Pollen Analysis, Blackwell, Oxford, 216 pp.

Müller P.J., Schneider R., 1993, An automated leaching method for the determination of opal in sediments and particulate matter, Deep-Sea Res. Part 1 40(3): 425-444.

Poraj-Górska A.I., Żarczyński M.J., Ahrens A., Enters D., Weisbrodt D., Tylmann W., (submitted), Impact of historical land-use changes on lacustrine sedimentation recorded in varved sediments of Lake Jaczno, northeastern Poland, Catena.

Rasmussen P., Anderson N.J., 2005, Natural and anthropogenic forcing of aquatic macrophyte development in a shallow Danish lake during the last 7000 years, J. Biogeogr. 32(11): 1993-2005.

Revelles J., van Geel B., 2016, Human impact and ecological changes in lakeshore environments. The contribution of non-pollen palynomorphs in Lake Banyoles (NE Iberia), Rev. Palaeobot. Palynol. 232: 81-97.

Stockmarr J., 1971, Tablets with spores used in absolute pollen analysis, Pollen et spores 13(4): 615-621.

Szal M., Kupryjanowicz M., Tylmann W., Piotrowska N., 2016, Was it 'terra desolata'? Conquering and colonizing the medieval Prussian wilderness in the context of climate change, Holocene, DOI: 10.1177/0959683616660167

Tipping R., 1995, Holocene landscape change at Carn Dubh, near Pitlochry, Perthshire, Scotland, J. Quat. Sci. 10(1): 59-75.

Tolonen M., 1980, Degradation analysis of pollen in sediments of Lake Lamminjärvi, S Finland, Ann. Bot. Fennici 17(1): 11-14.

Tweddle J.C., Edwards K.J., 2010, Pollen preservation zones as an interpretative tool in Holocene palynology, Rev. Palaeobot. Palynol. 161(1): 59-76.

Tylmann W., Bonk A., Goslar T., Wulf S., Grosjean M., 2016, Calibrating $210 \mathrm{~Pb}$ dating results with varve chronology and independent chronostratigraphic markers: problems and implications, Quat. Geochronol. 32: 1-10.

Tylmann W., Zolitschka B., Enters D., Ohlendorf C., 2013, Laminated lake sediments in northeast Poland: Distribution, preconditions for formation and potential for paleoenvironmental investigation, J. Paleolimnol. 50: 487-503.

Wacnik A., Tylmann W., Bonk A., Goslar T., Enters D., Meyer-Jacob C., Grosjean M., 2016, Determining the responses of vegetation to natural processes and human impacts in north-eastern Poland during the last millennium: combined pollen, geochemical and historical data, Veg. Hist. Archaeobot. 25(5): 479-498.

van Geel B., 2001, Non-pollen palynomorphs, [in:] Smol J.P., Birks H.J.B., Last W.M. (eds), Tracking Environmental Change Using Lake Sediments. Volume 3: Terrestrial, Algal, and Siliceous Indicators, Kluwer Academic Publishers, Dordrecht: 99-119.

van Geel B., Andersen S.T., 1988, Fossil ascopores of the parasitic fungus Ustulina deusta in Eemian deposits in Denmark, Rev. Palaeobot. Palynol. 56(1-2): 89-93.

van Geel B., Aptroot A., 2006, Fossil ascomycetes in Quaternary deposits, Nova Hedwigia 82(3-4): 313-329.

van Geel B., Buurman J., Brinkkemper O., Schelvis J., Aptroot A., van Reenen G., Hakbijl T., 2003, Environmental reconstruction of a Roman Period settlement site in Uitgeest (The Netherlands), with special reference to coprophilous fungi, J. Archaeol. Sci. 30(7): 873-883.

van Geel B., Coope G.R., Van Der Hammen T., 1989, Palaeoecology and stratigraphy of the Lateglacial type section at Usselo (The Netherlands), Rev. Palaeobot. Palynol. 60(1): 25-129.

van Geel B., Engels S., Martin-Puertas C., Brauer A., 2013, Ascospores of the parasitic fungus Kretzschmaria deusta as rainstorm indicators during a late Holocene beechforest phase around lake Meerfelder Maar, Germany, J. Paleolimnol. 50(1): 33-40.

van Geel B., Gelorini V., Lyaruu A., Aptroot A., Rucina S., Marchant R., Sinninghe Damsté J.S., Verschuren D., 2011, Diversity and ecology of tropical African fungal spores from a 25,000-year palaeoenvironmental record in southeastern Kenya, Rev. Palaeobot. Palynol. 164(3): 174-190.

Waters C.N., Zalasiewicz J., Summerhayes C., Barnosky A.D., Poirier C., Gałuszka A., Cearreta A., Edgeworth M., Ellis E.C., Ellis M., Jeandel C., Leinfelder R., McNeill J.R., Richter D. deB., Steffen W., Syvitski J., Vidas D., Wagreich M., Williams M., Zhisheng A., Grinevald J., Odada E., Oreskes N., Wolfe A.P., 2016, The Anthropocene is functionally and stratigraphically distinct from the Holocene, Science 351(6269): aad2622.

Smoll J.P., 2008, Pollution of lakes and rivers: a paleoenvironmental perspective, Wiley-Blackwell, Oxford, $383 \mathrm{pp}$.

Wilmshurst J.M., McGlone M.S., 2005, Corroded pollen and spores as indicators of changing lake sediment sources and catchment disturbance, J. Paleolimnol. 34: 503-517.

Zarzycki K., 1979, Zarys ekologii (Outline of ecology), [in:] Białobok S. (ed.), Brzozy, Betula L. (Birches, Betula L.), PWN, Warszawa-Poznań: 265-291 (in Polish).

Zolitschka B., Francus P., Ojala A.E., Schimmelmann A., 2015, Varves in lake sediments-a review, Quat. Sci. Rev. 117: 1-41. 